\title{
The Role of Travel Agencies' Abilities in Structural Changes of Rural Settlements of the Route and Destination of Tourism
}

\author{
By Naser Shafieisabet ${ }^{*} \&$ Saeideh Haratifard ${ }^{*}$
}

\begin{abstract}
Tourism and travel agencies play a crucial role in attracting tourists and organizing nature-friendly and clean tours, which can contribute to structural changes in rural settlements that serve as the route and destination of tourism. This research was undertaken to determine the role of abilities of tourism and travel agencies of Tehran in structural and functional changes of marginal rural settlements and opportunities that they provide in Tehran using a quantitativefield study method. The statistical population included 192 tourism and travel agencies in Tehran in 2017, which were selected from 947 tourism and travel agencies in Tehran (data was obtained from the Iran Cultural Heritage and Tourism Organization 2017), based on field studies and visits on these agencies. The sample size was calculated by Cochran formula and its modulation formula $(n=77)$, was selected using a systematic and random sampling method and direct inquiry. Data analysis was performed to explain the relationships between independent and dependent variables using SPSS 23 software. Findings of the research exhibited a significant relationship between the abilities of travel agencies and the number of organized tours. However, there is no meaningful relation between the abilities of travel agencies and so it is important to increase the rate of tourist attraction and to form and develop accommodation and catering infrastructure. Therefore, the abilities of travel agencies of Tehran, as endogenous factors, by raising awareness about the tourism attractions of Tehran and encouraging potential investors to venture on accommodation and catering infrastructure in the tourism destination, play a pivotal role in the improvement of the spatial system of Tehran, by supporting functional and structural changes.
\end{abstract}

Keywords: Travel agencies, Tehran, Rural and Tourism Development.

\section{Introduction}

Tourism developments, in terms of the number of tourists and the development of residential and catering infrastructure, have been affected by the expansion and capability of travel agencies, especially in recent decades. Travel agencies with appropriate notifications have increased tourism attraction, and as a result the structure of tourism in the tourism centers has changed (Aramberri and Butler 2005: 174-175, Marin-Pantelescu 2019).

Utilizing the facilities of advanced information technology and the efficient use of it by travel agencies in most tourist-receiving countries will help the

\footnotetext{
*Assistant Professor, Shahid Beheshti University, Iran.

"PhD Student, Shahid Beheshti University, Iran.
} 
improvement of the relationships of the tourism spatial organization. Providing information on the facilities and attractions of destinations and the reservation of places as a network of products delivered at destination have made it possible to attract customers more than ever (Fay 1992: 201, Badan 2007: 93, 177, Leung et al. 2015: 66). In terms of tourism, travel agencies in developed countries, by using the experienced and trained staff in accordance with international standards and by holding workshops and training conferences for the employees, enhance their performance, and as a result, they attract tourists increasingly, and develop infrastructure.

In this regard, in Iran and especially in Tehran, despite the relatively large expansion of travel and tourism agencies over the past two decades, there have been many problems in various structural fields, such as the weak Internet communication infrastructure, the unrelated education of office directors of the tourism specialty, the entry of unexperienced people into travel and tourism agencies and the lack of employment of tourism-related graduates at these agencies. Also, the emerging tourism education and the low level of awareness of new methods of notification and poor recognition of tourist attractions in the region of Tehran have reduced the quality of training courses and undermined the notification. In addition, the lack of logical communication between the managers and employees of travel and tourism agencies with the authorities of residential and catering centers in the tourist areas and the lack of participation of travel agencies and managers of residential and catering centers in the development of tourism rules and regulations caused that the motive for the investment in residential and catering infrastructure to be very weak in the tourism centers. Based on these challenges, the travel agencies in Tehran have not much succeeded in touring and attracting passengers and, as a result, in the development and expansion of residential and catering infrastructure. Therefore, it is of particular importance to study the spatial impact of technical capabilities and specialty of travel and tourism agencies in Tehran on the tourism attraction and the development of residential and catering infrastructure of tourism centers in the Tehran region for providing scientific solutions in this area.

\section{Theoretical Background}

Tourism has multifaceted concepts. Sankrusme (2017: 20), Smith (1988), Mieczkowski (1981), Hall and Page (1999) consider that: "researchers and scholars do not agree upon the concepts of tourism and have problems with the meanings and concepts of tourism". Therefore, there is no standard meaning for tourism that researchers can cite as a reference. As a result, researchers spend time on classification and controversial typologies rather than exploring and finding the real content of tourism, leisure or recreation. In this way, Pigram (1985) argues that tourism is a part of recreation and leisure time (Moses 2016), while Murphy (1985) poses the contrary. However, Dann and Cohen (1991) note that there are researchers who take an eclectic approach and do not rely on a particular theoretical approach. In this case, the researchers adapt to their chosen meanings 
according to the work needs. Smith (1988) states that researchers, international and national tourism associations, commercial companies and government agencies provide different definitions based on their understanding and the field of interest, so that research work sponsored by tourism and related policies ensure tendencies towards the tourism priorities (Awang et al. 2009: 67-70). However, researchers define tourism in their inferred field. In this regard, Jafari (1977) states: "Some researchers define tourism according to the anthropological perspective: Tourism is the study of human beings apart from their usual residence, and the study of this industry responds to their needs, as well as the study of the positive and the negative effects which affects both human beings and tourism in the social, cultural, economic, and physical environment of the host" (De Esteban et al. 2015: 8).

Murphy (1985), quoting Smith (1988), considers tourism as the total travel of non-resident people to destinations, until their residence is temporary and has not become a permanent residence. It is a combination of leisure and business. However, Shaw and Williams (1994) argue that the definition of the World Tourism Organization (WTO) for tourism and tourist is most commonly used in the tourism literature. "Anyone living in a country, regardless of nationality, who travels to a place within the country other than his permanent residence for less than 24 hours or one night, with a purpose, except for performing a mission in that location" (Vanhove 2011: 4, Jafari and Xiao 2016: 953). The motives of this trip can be:

1. Leisure (entertainment, holidays, treatment, study, education, religious and sports).

2. Business, family, mission, and meeting (WTO 1981: 89).

Smith $(1995,1988)$ argues that the definition of the WTO provides some guidelines for the collection of statistical information. Therefore, it provides a fully agreed-upon reference. These guidelines are not only a tool for researchers, governments, and institutions to measure and evaluate the growth of tourism within their borders, but also a tool for comparing them on a global scale (Awang et al. 2009: 70).

Smith (1988) and Britton (1991) argue that tourism function is largely devoid of a theoretical framework, which is due to the fact that many participants are trained in other related fields and thus, are not included in the introduction and complexity of social and cultural process variables. Tourism studies are concerning concepts and theories that are mainly taken from other social sciences, including geography. Although many researchers do not know its origin (Goeldner et al. 2000), the concepts and structures derived from geography often form the basis of research on tourism. However, dynamic processes involving tourism destinations can be understood using the techniques such as spatial analysis (Pearce 1995, Johnston 1997). On the other hand, Pearce (1979) identifies six major professional fields of geographic dimension in the study of tourism: spatial dimensions of supply, spatial dimensions of demand, patterns of tourism flow, tourism effects, geography of resorts, and tourism spatial models. 
Erstwhile, Oppermann (1993) suggest that the current tourism theories have been extended regarding two main patterns: the pattern of distribution and the pattern of dependency. Both patterns have the structure of spaces and places in nature (Crang 1997). However, in literature, tourism-related topics have been discussed as a regional growth factor. Therefore, tourism growth is spreading from the central to the peripheral regions (Awang et al. 2009: 73, Saarinen et al. 2017: 309). On the other hand, it considers the controlled peripheral region relative to the central region in the context of the peripheral countries to be fully examined (Brown and Hall 2000). Accordingly, the development of tourism in the peripheral centers of the regions and areas is entirely under the influence of events in the core centers. The massive flow of tourists from the core to peripheral centers focuses establishes the hotels, resorts, and so on (Britton 1991, Shafieisabet and Haratifard 2019). The role of travel agencies in the core centers as one of the most influential providers of tourism is due to their enormous financial resources, which can have a large impact on the occupancy of hotels and the spatial distribution of tourist flow in the receiving areas, many of which are similar to the peripheral areas (Shaw and Williams 1994). In this regard, Frank (1980) states: "The sectors of an underdeveloped economy, in fact, are integrated in the structure of the contiguous metropolitan relationships." As a pattern, he states that the whole chain of metropolitan area and surroundings is formed, and the commercial centers, tourism services, etc., flow from the metropolitan area to the peripheral centers (Papoli Yazdi and Rajabi Sanajerdi 2009: 99). Walpole and Goodwin maintain that the relationship between the core and peripheral tourism centers indicates that the distributive economic inequalities are more in favor of foreign operators and urban centers than rural settlements (Walpole and Goodwin 2000). In contrast, Shafieisabet and Haratifard (2015) consider a two-sided relationship between the core and the periphery, so that, in addition to the evolution and development of urban centers, it can provide employment for the local activists in the peripheral tourism centers (Shafieisabet and Haratifard, 2015: 6).

The global chain of events, including the economic recession created between the mid-1970s and the mid-1980s has led to an increase in neoliberalism and privatization in the development of tourism in many developing countries (Desforges 2000). Privatization and liberalization measures reduced the government role, and at the same time, provided the increasing role and importance of the private sector in the tourism industry (Awang et al. 2009: 70). According to the liberalism and neoliberalism view, the privatization and reduction of government role in the transformation and development of tourism has increased the share of the private sector in the tourism industry. In this context, the role of capabilities of travel agencies as one of the private enterprises in the structural changes in tourism is very significant (Haratifard 2009: 38).

Also, the results of the research by Negi (2004) in India show that travel agencies play a major role in attracting the tourists. If the government can expand the agencies and provide facilities for them, these agencies can attract a lot of tourists (Negi 2004: 143-144). The study of Badnjevic and Padukova (2006) in four major Indian cities shows that despite the remarkable impact of the information technology level in the developed countries, in India, despite the potential tourism 
opportunities, because of the relatively low level of information technology, lack of awareness and training of company employees of information technology and the bureaucratic dependences of the companies and physical problems in infrastructure and cultural and social laws governing different parts of India, tourism has not been developed as it should be (Badnjevic and Padukova 2006: 76). The studies of Koc (2003) in Turkey show that the lack of understanding of staff and managers about the motives and needs of tourists and the lack of brochures in tourist-receiving areas prevented the travel agencies from attracting tourists in a desirable level (Koc 2003:143-144). The studies in Iran showed that most people working in the field of tourism do not have enough experience and related education. As a result, due to the lack of knowledge and awareness of tourist attractions (such as providing information), they are not well notified about touristic attractions (Shafieisabet and Haratifard 2015). Josmani (2007 studied the criteria for choosing domestic travel tours in Malaysia. The research findings show that the experience and information of the tour guide and the appropriate means of transportation and the food intended for the travel package are effective in attracting tourists (Josmani 2007: 1). Campo (2008) stated that the quality of products and the awareness of the agencies of the tourist areas and the provision of desirable information influenced the loyalty of tourists to the travel agencies, and were effective in attracting tourists by travel tours and as a result, in tourism development (Campo 2008: 321-326). Therefore, based on the background of the research, the research hypothesis is formulated as follows: The desirable notification of travel and tourism agencies can have a major impact on the increase of tourist attraction and the changes in the tourism spatial system.

\section{Methodology}

In order to accurately explain the issues and research hypothesis, the present study uses a descriptive-analytical method with the quantitative field study to explore the impact and consequence of empowerment of Tehran travel agencies in the structural changes of tourism in Tehran. The background and field observations were used for explaining the research variables, so that the dependent variable of the research (structural changes) is assessed by indicators such as tourist attraction level, number of implemented travel tours, and change in the level of residential and catering infrastructure, and the indicators such as education and specialty of directors and staff of agencies, level of staff training for the knowledge of new methods, history of the agencies and the amount of notification are considered for the independent variable of the research (impact of notification of travel agencies in Tehran). The statistical population of the study consisted of 192 travel agencies operating in the field of tourism in Tehran. They were selected from 947 travel and tourism agencies in Tehran, ${ }^{1}$ based on the field survey and the visit of all of the agencies. The calculated sample size based on the Cochran formula and its adjustment formula is 77 agencies which were selected by the simple random

\footnotetext{
${ }^{1}$ Data comes from the Cultural Heritage and Tourism Organization 2016.
} 
sampling method and were directly questioned (Saraei 2012:136-137). To explain and analyze the data, descriptive statistics methods were used, and to compare the two groups of agencies that were or were not notified about the tourism in Tehran, the Kruskal-Wallis test was used, and also to determine the relationship between the independent and dependent variables of the research, the Spearman correlation coefficients and the chi-square test and t-test were used.

\section{Analysis of Results}

\section{Capability of Tourism Spatial System in Tehran}

The non-urban spaces of the Tehran area feature great natural, historical and cultural capabilities and attractions for attracting the tourists, so that in different mountainous, plain and desert territories according to different seasons and geographical features, they are suitable for all types of travel tours (Table 1). Also, due to the proximity of Tehran tourism centers to the Tehran metropolitan area and the vast need of residents of other major cities in Tehran metropolitan system, various territories of Tehran are well suited to the leisure time and tourism during the week for the revitalization and relief of fatigues (Haratifard 2009: 88-104). Hence, in the past two decades, tourism in the non-urban areas of Tehran has become widespread in different seasons, so that according to the data from the Iranian Center for Statistics in 2016, the hotel and restaurant sectors as the major tourism-related sectors employed 33,137 people in the region of Tehran, which accounts for about $2.1 \%$ of the employees in the service sector of Tehran and $1.6 \%$ of the service sector in the Tehran region. Also, in the region of Tehran, there were 1051 travel and tourism agencies, with an average of 5 people working people and a total of 5,255 people employed in these agencies (ibid: 111-112).

\section{Education Degree and Type of Managers and Staff of Travel Agencies}

The research findings showed that about $24.7 \%$ of managers had education lower than bachelor degree, $64.9 \%$ at the bachelor level and $10.4 \%$ had master degree and higher. The result of Kruskal-Wallis test shows that there was no significant difference between the level of education and the level of tourism attraction by Tehran travel agencies in the $95 \%$ confidence level. In other words, the increased level of education, in addition to reducing the tourist attraction, has made the situation more consistent in this regard (Table 2). 
Table 1. Spatial Distribution of Tourism Areas by Number of Tours and Number of Tourists in Non-Urban Spaces of Tehran Region in 2016

\begin{tabular}{|l|c|c|}
\hline \multicolumn{1}{|c|}{ Place name } & Number of tours & Number of tourists \\
\hline Ab Ali & 1 & 30 \\
\hline Emamzadeh Davood & 16 & 330 \\
\hline Tangeh Vashi & 999 & 23,737 \\
\hline Darband & 1 & 15 \\
\hline Darreh Ousoon & 1 & 30 \\
\hline Tar Lake & 7 & 150 \\
\hline Shekar Ab & 2 & 50 \\
\hline Rudafshan Cave & 1 & 20 \\
\hline Fasham & 5 & 100 \\
\hline Taleghan & 161 & 3,095 \\
\hline Gachsar & 4 & 100 \\
\hline Dizin & 76 & 2,095 \\
\hline Shemshak & 31 & 900 \\
\hline Shahrestanak & 29 & 580 \\
\hline Maranjab desert & 35 & 1,015 \\
\hline Gajareh & 6 & 240 \\
\hline Chalous Road & 12 & 250 \\
\hline Lar Dam & - & - \\
\hline Total & 1,387 & 32,737 \\
\hline Sotc: Daf & & 2016. \\
\hline
\end{tabular}

Source: Data from 77 travel and tourism agencies of random sample of Tehran in 2016.

Table 2. Distribution of Respondents according to Level of Education of Travel Agencies Managers in Tehran Until 2016

\begin{tabular}{|l|c|c|c|c|}
\hline No. & Education level & Number & Percentage & Average classification \\
\hline 1 & Diploma & 17 & 22.1 & 32.15 \\
\hline 2 & Advanced Diploma & 2 & 2.6 & 49.25 \\
\hline 3 & Bachelor & 50 & 64.9 & 39.34 \\
\hline 4 & Master degree and higher & 8 & 10.4 & 48.88 \\
\hline Total & & 77 & 100.0 & - \\
\hline
\end{tabular}

The significance level calculated according to Kruskal-Wallis test is equal to 0.308. Since the level of significance is more than $5 \%$, the relationship is not significant.

In fact, about $75 \%$ of travel agency managers had a bachelor degree and higher, but only $19.5 \%$ had expertise in tourism. The education of about $80 \%$ of agency managers was unrelated to tourism. This issue also applies to office staff, so that about $52 \%$ of the staff had bachelor degree or higher, of which about $20 \%$ were educated in tourism. Therefore, the unrelated type of education for the staff and managers was an effective factor in the failure of the travel agencies in Tehran to increase the number of tours and the tourist attraction level. 
Level and Type of Training for Managers and Staff of Agencies and their History of Activities

Based on the information obtained from the questionnaire of travel agencies in Tehran, $90.9 \%$ of managers and employees had completed their training courses by 2016 and $9.1 \%$ did not attend any training courses. Among those who completed the courses, $45.7 \%$ attended the technical management course, $15.7 \%$ the ticket sales and $2.9 \%$ the tour guide course, and $27.1 \%$ of the managers and staff attended the technical management and ticket sales courses. The result of Kruskal-Wallis correlation test showed that there was no significant difference between the training courses taken by the managers and staff of the agencies and the number of implemented tours $(\mathrm{P}>0.232)$. In other words, taking various courses in the field of tourism not only had no effect on the increase in the number implemented tours, but also contributed to the more consistent situation of the agencies in terms of number of tours (Table 3 ).

Table 3. Distribution of Respondents in Terms of Implemented Training Courses Taken by Managers of Travel Agencies in Tehran in Field of Tourism Attraction Until 2016

\begin{tabular}{|l|c|c|c|c|}
\hline No. & Education courses & Number & Percentage & $\begin{array}{c}\text { Average } \\
\text { classification }\end{array}$ \\
\hline 1 & Technical management & 32 & 45.7 & 29.44 \\
\hline 2 & Ticket sales & 11 & 15.7 & 40.14 \\
\hline 3 & Tour guide & 2 & 2.9 & 44.00 \\
\hline 4 & $\begin{array}{c}\text { Technical management and } \\
\text { ticket sales }\end{array}$ & 19 & 27.1 & 37.29 \\
\hline 5 & $\begin{array}{c}\text { Technical management and tour } \\
\text { guide }\end{array}$ & 1 & 1.4 & 36.00 \\
\hline 6 & $\begin{array}{c}\text { Technical management, ticket } \\
\text { sales and tour guide }\end{array}$ & 4 & 5.7 & 53.75 \\
\hline 7 & Ticket sales and tour guide & 1 & 1.4 & 54.00 \\
\hline Total & & 70 & 100.0 & - \\
\hline
\end{tabular}

The significance level calculated according to Kruskal-Wallis test is equal to 0.232 . Since the level of significance is more than $5 \%$, the relationship is not significant.

The reason for the insignificant effect of the training courses taken by the managers and staff on the tourist attraction level and the number of implemented tours, in addition to the unrelated education degree of managers and staff of agencies to tourism, is the low level of courses and the short tenure duration for the managers and staff is in the field of touring and the job change for most of them. Thus, the experience of most staff and managers of travel agencies in Tehran is short for attracting tourists and the provided training courses are also wasted.

In this regard, the research findings showed that $37.7 \%$ of travel agencies in Tehran had a history of 1 to 5 years, 32.5\% were between 6 and 10 years, about 5\% between 15 and 30 years, and around 5\% have more than 30 years of experience. Altogether, about $70 \%$ of agencies had the history of establishment less than 10 years and about $90 \%$ had less than 20 years (Table 4 ). 
Table 4. Distribution of Respondents according to History of Establishment of Travel Agencies in Tehran in Terms of Tourist Attraction until 2016

\begin{tabular}{|l|c|c|c|}
\hline Establishment history (years) & Number & Percentage & Cumulative percentage \\
\hline $1-5$ & 29 & 37.7 & 37.7 \\
\hline $6-10$ & 25 & 32.5 & 70.2 \\
\hline $11-15$ & 15 & 19.4 & 89.6 \\
\hline $16-20$ & 3 & 3.9 & 93.5 \\
\hline $21-25$ & 0 & 0 & 93.5 \\
\hline $26-30$ & 1 & 1.3 & 94.8 \\
\hline More than 30 years & 4 & 5.2 & 100 \\
\hline Total & 77 & 100 & - \\
\hline
\end{tabular}

The significance level calculated based on chi-square test is 0.002 in relation to the tourist attraction level. Since the significance level is less than 5\%, the relationship is significant.

The Chi-square test showed that there is a significant difference between the tourist attraction level by Tehran travel agencies in relation to tourism in Tehran and the history of agency activities $(\mathrm{P}<0.05)$. That is, the more experience the travel agencies, the more the number of implemented tours and the number of attracted tourists in the region of Tehran.

\section{Knowledge and Notification of Agencies of Tourist Attractions in Tehran Region}

Based on the data of the questionnaire of travel agencies in Tehran, about $40 \%$ of travel agencies had little or very little knowledge of the tourist attractions of the rural centers of the Tehran region. $32.3 \%$ had fair and $27.7 \%$ had high knowledge of the tourist attractions of Tehran. The limited knowledge of the staff and managers of travel agencies in Tehran in terms of tourist attractions in Tehran area affects their notification, so that $27.3 \%$ of the agencies had a low notification level, $29.9 \%$ fairly notified, and $42.8 \%$ highly notified of tourists through advertisements in newspapers, agency website, internet, brochures, leaflets, SMSs, faxes, contracts with companies and government agencies in the field of provincial tours (Table 5).

Table 5. Distribution of Respondents according to Notification Level of Travel Agencies in Tehran in Field of Tourist Attraction up to 2016

\begin{tabular}{|l|c|c|c|c|c|c|}
\hline \multirow{2}{*}{$\begin{array}{c}\text { Notification } \\
\text { level }\end{array}$} & \multicolumn{3}{|c|}{ Number of tours } & \multicolumn{3}{c|}{ Number of tourists } \\
\cline { 2 - 7 } & $\begin{array}{c}\text { Number } \\
\text { of } \\
\text { agencies }\end{array}$ & Percentage & $\begin{array}{c}\text { Average } \\
\text { classification }\end{array}$ & $\begin{array}{c}\text { Number } \\
\text { of } \\
\text { agencies }\end{array}$ & Percentage & $\begin{array}{c}\text { Average } \\
\text { classification }\end{array}$ \\
\hline Low & 21 & 27.3 & 21.9 & 21 & 27.3 & 23.19 \\
\hline Medium & 23 & 29.9 & 41.15 & 23 & 29.9 & 37.54 \\
\hline High & 33 & 42.8 & 48.83 & 33 & 42.8 & 50.08 \\
\hline Total & 77 & 100 & - & 77 & 100 & - \\
\hline
\end{tabular}

The significance level calculated based on Kruskal-Wallis test between the notification level and the number of tours implemented in Tehran province is $\mathrm{P}=0.000$. Also, this calculation for the notification level variable and the tourist attraction level is also $\mathrm{P}=0.000$. Since the significance level is less than $5 \%$ in both variables, number of tour and tourist attraction level, the relationship is significant. 
The results of Kruskal-Wallis test showed that there is a significant difference between the notification level and the number of implemented tours and the tourist attraction level $(\mathrm{P}=0.000)$. That is, the higher the notification level and activity of travel agencies in this field, the higher the tourist attraction level and number of tours.

\section{Development and Expansion of Residential and Catering Infrastructure}

In the review of travel agency questionnaire data in Tehran, it was found that there is no significant relationship between the tourist attraction and the amount of residential and catering infrastructure during 2015-2016. As the significance level $\mathrm{F}(0.057)$ indicated, there is no significant difference between the tourist attraction level and the amount of residential and catering infrastructure (Table 6). In fact, the tourist attraction level and the amount of residential and catering infrastructure are not proportional, so that many tourist centers of the non-urban areas of Tehran annually attract a lot of tourists, but lack the least amount of residential and catering infrastructure. In other words, the tourist centers of Tangeh Vashi, Rudafshan Cave, Tar Lake, Shahrestanak, and Varamin Desert having the most tourism destinations lack any residential and catering infrastructure and the sanitation facilities. Also, the tourism centers of Ab Ali, Emamzadeh Davood, Fasham, Gachsar, and Chalous Roads are of medium infrastructure, and only the tourism centers of Shemshak, Dizin and Gajareh have good infrastructure facilities.

Table 6. Relationship between Tourism Attraction Level and Amount of Residential and Catering Infrastructure in Tourist Centers of Tehran Province in 2016

\begin{tabular}{|l|c|c|c|c|c|}
\hline \multicolumn{1}{|c|}{$\begin{array}{c}\text { Change } \\
\text { Source }\end{array}$} & $\begin{array}{c}\text { Squared sum } \\
\text { (SS) }\end{array}$ & $\begin{array}{c}\text { Degree of } \\
\text { freedom (df) }\end{array}$ & Mean square (MS) & F & Sig. \\
\hline Intergroup & 7218344.282 & 2 & 3609172.141 & 11.428 & 0.057 \\
\hline Intragroup & EV2.305 EV & 73 & 315806.102 & & \\
\hline Total & $3.027 \mathrm{EV} \mathrm{EV}$ & 75 & & & \\
\hline
\end{tabular}

According to the calculations carried out in relation to the situation of residential and catering infrastructure of the tourism centers of Tehran, among the total 77 travel agencies in Tehran, 66 agencies equal to $85.7 \%$ had low amount of residential and catering infrastructure for tourism centers where the tours are implemented, 6 agencies equal to $7.8 \%$ had moderate amount of infrastructure, and finally, 5 agencies equal to $6.5 \%$ had large amount of infrastructure. The significance level between the amount of residential and catering infrastructure and the tourists $(\mathrm{P}>0.315)$ indicates that there is no significant relationship between the two variables with $95 \%$ confidence level (Table 7). 
Table 7. Situation of Residential and Catering Infrastructure of Tehran Tourism Centers in Terms of Office Managers Until 2016

\begin{tabular}{|l|c|c|c|c|}
\hline \multirow{2}{*}{ Infrastructure Situation } & \multirow{2}{*}{ Number } & \multirow{2}{*}{ Percentage } & \multicolumn{2}{|c|}{ Subset for alpha = 0.05 } \\
\cline { 4 - 5 } & & & 1 & 2 \\
\hline Low & 66 & 85.7 & 308.74 & \\
\hline Medium & 6 & 7.8 & 1014.17 & 1014.17 \\
\hline High & 5 & 6.5 & & 1455.00 \\
\hline Total & 77 & 100.0 & Sig. 0.057 & Sig. 0.315 \\
\hline
\end{tabular}

Tukey HSD ${ }^{\mathrm{a}, \mathrm{b}}=6.947$, Sig. 0.315 .

Although relatively good information is provided on tourism centers and there is a positive significant correlation between the agency notification and the number of implemented tours and the tourist attraction, (99\% confidence level) $(\mathrm{P}=0.000)$, there is no significant positive correlation between the notification level of agencies and the development of residential infrastructure $(\mathrm{P}>0.254)$. Also, there is no significant positive correlation between the notification level of agencies and the amount of catering infrastructure $(\mathrm{P}>0.143)$. Table 8 shows the relationship between the independent and dependent variables in this regard.

Table 8. Relationship between Notification level of Travel Agencies and Tourist Attraction Level and Amount of Residential and Catering Infrastructure by 2016

\begin{tabular}{|l|c|c|c|}
\hline \multicolumn{1}{|c|}{ First variable } & Second variable & $\mathbf{r}_{\mathbf{s}}$ & $\mathbf{P}$ \\
\hline \multirow{4}{*}{$\begin{array}{l}\text { Notification level of travel and } \\
\text { tourism agencies in Tehran }\end{array}$} & $\begin{array}{c}\text { Number of implemented } \\
\text { travel tours }\end{array}$ & $0.749^{* *}$ & 0.000 \\
\cline { 2 - 4 } & Tourist attraction & $0.763^{* *}$ & 0.000 \\
\cline { 2 - 4 } & $\begin{array}{c}\text { Number of residential } \\
\text { infrastructure }\end{array}$ & 0.114 & 0.254 \\
\cline { 2 - 4 } & $\begin{array}{c}\text { Number of catering } \\
\text { infrastructure }\end{array}$ & 0.218 & 0.143 \\
\hline
\end{tabular}

\section{Conclusions and Suggestions}

The structural changes in tourism in the non-urban spaces of the Tehran region, rather than a change for the comprehensive and endogenous development of tourism based on the recognition of capabilities and the spatial constraints, is a one-dimensional change merely made to increase the relative number of tourists, so that the travel agencies of Tehran have been effective as an endogenous factor in the tourism spatial system for the implementation of travel tours on the level of tourist attraction. This issue is similar to the results of Lickorish and Jenkins (1997), Santos (1998), Koc (2003), Negi (2004), Badnjevic and Padukova (2006), Josmani (2007), Campo (2008), Shafieisabet and Haratifard (2019) but did not succeed in developing and expanding the residential and catering infrastructure. Such a process reflects the different characteristics of the tourism spatial system of Tehran in comparison with previous studies in other countries and is not similar to the findings of previous researchers. Therefore, unlike other tourism centers in the 
previously investigated regions, in the non-urban spaces of Tehran, there is a particular form of tourism, mostly of one-day. In the places where tourists tend to stay overnight or a few days, they are forced to use tents. Thus, tourism and touring in the Tehran region does not have a significant profitability. In this way, travel agencies do not have the motive to expand travel tours in the region of Tehran, and therefore, they do not provide much information on the field of tourism centers in Tehran. Also, the unrelated type of education of staff and managers of the agencies of tourism expertise, the low level of courses in expertise training, the short tenure duration of managers and staff in the field of touring, the job changes due to the low profitability of touring in Tehran region, the low capability and knowledge of the agencies of the attractions and tourism centers in the non-urban areas of Tehran, and consequently the lack of reasonable communication with the owners of existing residential and catering facilities and those who are willing to invest in the residential and catering infrastructure, caused insufficient investment for developing and expanding residential and catering infrastructure. Therefore, in order to overcome the existing challenges, the following suggestions and strategies are presented based on the scientific findings of this research and the views of managers and staff:

- Use experienced professors to introduce to the managers and staff of the agencies, the natural, religious, cultural and historical attractions in the region of Tehran and the tourism activities applicable in each one of the tourism areas.

- Introduce to the managers and staff, innovative ways of notification and marketing.

- Introduce tourism places and routes in the Tehran region through the map and brochure and provide them free of charge to the agencies and tourists through the website of the Cultural Heritage and Tourism Organization or by simple delivery to the agencies.

- Introduce residential and catering facilities in Tehran to notify managers and staff of agencies and tourists about the availability of residential and catering centers in the touristic areas.

- Adopt supportive policies by the Cultural Heritage and Tourism Organization to encourage agencies to closely cooperate with the hoteliers and restaurant owners for developing and expanding residential and catering infrastructure of tourism destinations.

- Improve information infrastructure, such as creating a network of tours designed by the agencies, connecting agencies together and strengthening the online tour reservation.

- Prepare and provide documentary reports of regional attractions and related touristic seasonal activities in the media to encourage people to travel to these areas.

- Facilitate the rules and regulations for investment in tourism in the region of Tehran.

- Notify tourists of group trips and their benefits. 
In addition to the above points, the change in the spatial tourism system will cause significant physical-spatial changes in the urban and rural areas of Tehran.

\section{Notes}

(1) How to calculate sample size:

$\mathrm{n}=\mathrm{N} . \mathrm{t}^{2}$.p.q./N. $\mathrm{d}^{2}+\mathrm{t}^{2}$.p.q.

$\mathrm{N}=$ Statistical population (192 agencies)

$\mathrm{n}=$ Sample size

$\mathrm{P}=0.5$, Probability of effect of independent variable on dependent variable

$\mathrm{q}=0.5$, Probability of lack of effect of independent variable on dependent variable

$\mathrm{t}=1.96$, with $95 \%$ confidence level

$\mathrm{d}=0.05$, degree of confidence

$\mathrm{n}=192 \cdot(1.96)^{2} \cdot 0.5 \cdot 0.5 / 192 \cdot(0.05)^{2}+(1.96)^{2} \cdot 0 / 5 \cdot 0 / 5=128$

And the ratio of $\mathrm{n}$ to $\mathrm{N}$ for this estimate is adjusted by the following formula:

$\mathrm{n}=\mathrm{n} / 1+\mathrm{n} / \mathrm{N}=128 / 1+0.66=128 / 1.66=77$

\section{References}

Aramberri J, Butler R (2005) Tourism development. Great Britain: Cromwell Press.

Awang KW, Wan Melissa WH, Mohd Zahari MS (2009) Tourism development: A geographical perspective. Asian Social Science 5(5): 67-76.

Badan BS (2007) Travel agencies and tourism management. India: Commonwealth.

Badnjevic J, Padukova L (2006) Act awareness in small enterprises in the Indian tourism branch. Germany: Goteborg University.

Britton SG (1991) Tourism, capital, and place: towards a critical geography of tourism development. Environment and Planning D: Society and Space 9(4): 451-78.

Brown F, Hall D (2000) Introduction: the paradox of peripherality. In F Brown, D Hall (Eds.), Tourism in Peripheral Areas: Case Studies, 1-6. Clevedon: Channel View Publications.

Campo S (2008) Tourist loyalty to tour operator: effects of price promotions and tourists effort. Journal of Travel Research 46(3): 318-326.

Crang P (1997) Performing the tourist product. In C Rojek, J Urry (Eds.), Touring Cultures: Transformation of Travel and Theory, 137-154. London: Routledge.

Dann GMS, Cohen E (1991) Sociology and Tourism. Annals of Tourism Research 18(1): 155-169.

De Esteban J, Cetin G, Antonovica A (2015) Theory of knowledge of tourism: a sociological and epistemological reflection. Journal of Tourismology 1(1): 2-15.

Desforges L (2000) State tourism institutions and neo-liberal development: a case study of Peru. Tourism Geographies 2(2): 177-192.

Fay B (1992) Essentials of tour management. USA: Prentice - Hall.

Frank AG (1980) Crisis: in the world economy. New York: Holmes \& Meier.

Goeldner CR, Ritchie JR, McIntosh RW (2000) Tourism Principles, Practices, Philosophies. New York: John Wiley and Sons.

Hall CM, Page SJ (1999) The geography of tourism and recreation: environment, place and space. London: Routledge. 
Haratifard S (2009) Role of providing information by tour and travel agencies of Tehran city in tourism development of Tehran province. Master Thesis. Tehran: Geography Department, Literature and the Humanities Faculty, Islamic Azad University.

Jafari J (1977) Editor's page. Annals of Tourism Research 5(Special issue): 6-11.

Jafari J Xiao H (Eds) (2016) Encyclopedia of tourism. Cham: Springer.

Johnston RJ (1997) Geography and geographer: Anglo-American human geography since 1945. $5^{\text {th }}$ Edition. London: Wiley.

Josmani D (2007) Study on the selection criteria for choosing domestic package tours in Malaysia. Malaysia: Faculty of Built Environment, University Technology Malaysia.

Koc E (2003) An analysis of consumer behavior in the Turkish domestic tourism market. Turkey: Dogus University Dergisi, 89-106.

Leung YF, Spenceley A, Hvenegaard G, Buckley R (2015) Tourism and visitor management in protected areas. Gland: IUCN.

Lickorich L, Jenkins C (1997) An introduction to tourism. Great Britain: ButterworthHeinemann.

Marin-Pantelescu A, Tăchiciu L, Căpuşneanu S, Topor DI (2019) Role of tour operators and travel agencies in promoting sustainable tourism. Amfiteatru Economic 21(52): 654-669.

Mieczkowski Z (1981) Some notes on the geography of tourism: a comment. Canadian Geographer 25(2): 186-191.

Moses AO (2016) Planning valued landscapes as potential tourism attractions for national development: the case of Yoruba, Nigeria. Geografia. Malaysian Journal of Society and Space 12(9): 1-10.

Murphy PE (1985) Tourism: a community approach. London: Routledge.

Negi J (2004) International tourism \& travel. India: Scand \& Company.

Oppermann M (1993) Tourism space in developing countries. Annals of Tourism Research 20(3): 535-555.

PapoliYazdi MH, Rajabi Sanajerdi H (2009) Urban and the suburbs theories. Tehran: Samt Press.

Pearce DG (1995). Tourism today: a geographical analysis. $2^{\text {nd }}$ Edition. Harlow: Longman.

Pigram JJ (1985) Outdoor recreation and resource management. $2^{\text {nd }}$ Edition. London: Croom Helm.

Saarinen J, Rogerson CM, Hall CM (2017) Geographies of tourism development and planning. Tourism Geographies - An International Journal of Tourism Space, Place and Environment 19(3): 307-317.

Sankrusme S (2017) Potential development strategies on marine and beach tourism. Hamburg: Anchor Academic Publishing.

Santos J (1998) The role of tour operators promotional material in the information of destination image and consumer exceptions. Journal of Vacation Marketing 3(4): $282-297$.

Saraei H (2012) Preliminary on sampling in research. $1^{\text {st }}$ Edition. Tehran: Samt Press. (In Persian).

Shafieisabet N, Haratifard S (2015) The impact of cooperation of tour operators in sustainability and development of local settlements (case study: Tehran and Alborz regions). Journal of Tourism Planning and Development 4(13): 93-119.

Shafieisabet N, Haratifard S (2019) Empowerment of local stakeholders for participation in sustainable tourism development with mediating role of perceived tourism effects. Journal of Tourism Planning and Development 8(29): 71-90.

Shaw G, Williams AM (1994) Critical issues in tourism: a geographical perspective. Oxford: Blackwell.

Smith SLJ (1988) Defining tourism: a supply-side view. Annals of Tourism Research 
15(2): 179-190.

Smith SLJ (1995) Tourism analysis: handbook. $2^{\text {nd }}$ Edition. Harlow: Longman.

Vanhove $\mathrm{N}$ (2011) The economics of tourism destinations. $2^{\text {nd }}$ Edition. Elsevier.

Walpole MJ, Goodwin HJ (2000) Local economic impact of dragon tourism in Indonesia. Annals of Tourism Research 27(3): 559-576.

World Tourism Organization - WTO (1981) Tourism multiplier explained. Madrid World Tourism Organization and Horwarth. 
